\title{
THE VARIATIONS OF THE EXHAUST EMISSIONS AT LOW AMBIENT TEMPERATURE FOR E10 AND M10 FUELED SI ENGINE
}

\author{
Tolga TOPGÜL*, Can CINAR** and A. Onur OZDEMIR*** \\ Department of Automotive Engineering, Faculty of Technology, Gazi University, 06560, Ankara, Turkey \\ *topgul@gazi.edu.tr, ORCID: 0000-0003-1347-9594 \\ **cancinar@gazi.edu.tr; ORCID: 0000-0001-6944-8864 \\ ***onurozdemir@gazi.edu.tr; ORCID: 0000-0002-6475-1976
}

(Geliş Tarihi: 23.02.2021, Kabul Tarihi: 03.10.2021)

\begin{abstract}
Biomass fuels are important alternatives to conventional energy sources such as petroleum-based fuels. Biomass fuels especially alcohols have been used in passenger cars. Alcohol blends with gasoline constitute a general use. Particularly, modification of the engine is not required when using at low rates, like gasohol. Gasohol consists of a mixture of gasoline and especially ethanol, and it contains generally 10 percent alcohol. This study deals with the effect of the usage of low alcohol containing (10\% ethanol or $10 \%$ methanol) blends on the exhaust emissions caused by an SI engine in the 600 seconds of the engine's operating period from the cold start-up. According to the experimental results, the leaning effect of alcohol on the emissions is clearer in the initial 150 seconds of the experiments. The engineout $\mathrm{CO}$ emissions decreased on average 34.5\% for E10 fuel and 44.8\% for M10 fuel compared to unleaded gasoline. Also, in the first 150 seconds, an average reduction of 23.2\% E10 fuel and 25\% M10 was observed in HC. When it comes to the engine-out NO, there were no significant differences by fuel type. Besides, in the study, the tailpipe emissions and converter efficiency were examined by heating the catalytic converter without changing other experimental conditions. Emissions were significantly reduced in all fuels, while efficiency reached $100 \%$, especially for $\mathrm{CO}$ emissions.
\end{abstract}

Keywords: Spark Ignition Engine, Exhaust Emissions, Catalytic Converter, Alternative Fuels

\section{DÜŞÜK ÇEVRE SICAKLIĞINDA E10 VE M10 YAKITLI BUJI İLE ATEŞLEMELİ BİR MOTORDA EGZOZ EMISYONLARININ DEĞISŞIMI}

Özet: Biyokütle yakıtları, petrol bazlı yakıtlar gibi geleneksel enerji kaynaklarına önemli alternatiflerdir. Biyokütle yakıtlar özellikle alkoller binek araçlarda kullanılmaktadır. Alkollerin benzinle karışımları genel kullanım alanını oluşturmaktadır. Özellikle benzinol gibi düşük oranlarda kullanıldığında motorda değişiklik yapılmasına gerek yoktur. Benzinol, benzin ve özellikle etanolden meydana gelen bir karışımıdır ve genellikle yüzde 10 alkol içerir. Bu çalışma, düşük oranda alkol içeren (\% 10 etanol veya\% 10 metanol) karışımların kullanımının, motorun soğuk çalıştırmadan sonraki 600 saniyede içerisinde buji ile ateşlemeli bir motorunun neden olduğu egzoz emisyonları üzerindeki etkisini ele almaktadır. Deney sonuçlarına göre, alkolün fakirleştirici etkisinin emisyonlar üzerindeki etkisi deneylerin ilk 150 saniyesinde daha nettir. Motor çıkışındaki CO emisyonu kurşunsuz benzine göre ortalama olarak E10 yakıtı ile \% 34,5 ve M10 yakıtında \% 44,8 azaldı. Ayrıca HC emisyonu, E10 yakıtında ilk 150 saniyede ortalama olarak \% 23,2 ve M10'da \% 25 azalma gözlenmiştir. Motor çıkışındaki NO söz konusu olduğunda, yakıt türüne göre dikkate değer bir fark yoktur. Ayrıca çalışmada, diğer deneysel koşulları değiştirmeden katalitik konvertör ısıtılarak egzoz uç çıkışındaki emisyonlar ve konvertör verimi incelenmiştir. Tüm yakıtlarda emisyonlar önemli ölçüde azaltılırken verimlilik, özellikle CO emisyonlarında\% 100'e ulaştı.

Anahtar Kelimeler: Buji ile Ateşlemeli Motor, Egzoz Emisyonları, Katalitik Konvertör, Alternatif Yakıtlar

\section{NOMENCLATURE}

$\begin{array}{ll}\text { AFR } & \text { Air/Fuel Ratio } \\ \text { ATDC } & \text { After Top Dead Center } \\ \text { BTDC } & \text { Before Top Dead Center } \\ \text { CO } & \text { Carbon monoxide } \\ \text { ECU } & \text { Electronic Control Unit } \\ \text { HC } & \text { Hydrocarbons } \\ \text { LPG } & \text { Liquefied Petroleum Gas } \\ \text { MON } & \text { Motor Octane Number } \\ \text { NO }_{x} & \text { Nitrogen Oxides } \\ \text { RON } & \text { Research Octane Number }\end{array}$

$\begin{array}{ll}\text { SI } & \text { Spark Ignition } \\ \text { TDC } & \text { Top Dead Center } \\ \text { THC } & \text { Total Hydrocarbon } \\ \text { UG } & \text { Unleaded Gasoline }\end{array}$




\section{INTRODUCTION}

The main pollutants that deal with spark-ignition engines are carbon monoxide (CO), hydrocarbons (HC), nitrogen oxides which are $\mathrm{NO}$ and $\mathrm{NO}_{2}$ generally and organic toxics. These pollutants come out due to incomplete combustion of the fuel, peak temperatures and oxygen concentration in the combustion chamber, quench effect, cold regions and narrow gap areas where the flame does not propagate, and absorption and desorption of fuel hydrocarbon components in the oil film (Hochgreb 1998; Abdel-Rahman 1998; Schäfer and Basshuysen 1995; Mondt 2000; Heywood 1998; Yu and Min 2002; Shayler et al. 1999; Çelikten et al. 2015).

Emissions caused by transportation, which has become a basic need today, are important issue that attracts the attention of researchers due to their effects on human beings and the environment. Generally, studies on emissions are aimed at reducing them or their effects. Another issue related to this issue is alternative energy sources. The issue of using alternative fuels in internal combustion engines has attracted researchers' attention for a long time. In particular, alternative fuels, which are biomass, reduce the need for petroleum thanks to their properties and their ability to be used in internal combustion engines, such as using alcohol fuels as an alternative fuel for an SI engine.

Alcohol fuels like ethanol and methanol have properties like good knock resistance, possession of oxygen, cleanburning characteristics, high autoignition temperature, low freezing point, and high latent heat of vaporization, which have significant impacts on combustion efficiency, engine performance, and emissions (Mills and Ecklund 1987; Speight 2011; Bechtold 1997; Şimşek et al. 2019; Datta and Mandal 2017).

Shenghua et al. (2007) studied the effect of methanol/gasoline blends on an SI engine. They emphasized that adding methanol to gasoline would improve the SI engine cold start and significantly reduce $\mathrm{CO}$ and $\mathrm{HC}$ emissions, but this would not have an apparent effect on the efficiency of the converter. They found that $\mathrm{M} 30$ could provide a decrease in $\mathrm{CO}$ by $25 \%$ and $\mathrm{HC}$ by $30 \%$ in the warming-up period at $5^{\circ} \mathrm{C}$.

Nabi et al. (2020) examined emissions during cold and hot start operations using oxygenated fuels in a turbocharged diesel engine. The cold operation was defined as $22{ }^{\circ} \mathrm{C} \pm 1{ }^{\circ} \mathrm{C}$ of the ambient temperature and the hot start operation was described as the minimum of 60 minutes of running the engine for warming in this study. The researchers expressed that oxygenated blends decreased specific particulate matter emissions by $26.2 \%-42.9 \%$ and $30 \%-50.6 \%$ during cold and hot conditions, respectively. While a similar effect was seen on particulate number emissions, specific $\mathrm{NO}_{\mathrm{x}}$ emissions increased in oxygenated blends. They obtained an increase in the specific $\mathrm{NO}_{\mathrm{x}}$ emissions during cold operation by $1.00 \%-7.80 \%$ and hot start operation by $4.20 \%-11.94 \%$.
Baskar and Senthilkumar (2016) researched the effect of oxygen enrichment on the emissions and performance of a diesel engine. They emphasized that the $\mathrm{CO}$, unburned hydrocarbon, and particulates emissions would be decreased by oxygen-enhanced combustion. Also, oxygen enrichment provided a rising in thermal efficiency and a reduction in the brake specific fuel consumption. Contrary to these outcomes, it was noted that $\mathrm{NO}_{\mathrm{x}}$ emissions increased.

Arce-Alejandro et al. (2018) investigated the effect of nbutanol, ethanol and n-butanol blends, and gasoline on performance and pollutants in an SI engine. They reported using alcohol may increase the $\mathrm{CO}$ and $\mathrm{HC}$ in their experimental conditions. On the other hand, HC emissions decreased with the help of an increase in ethanol content in the blend. Nevertheless, engine performance was not significantly influenced by the ethanol in the mixture. Finally, gasoline led to higher nitrogen oxides at low engine speeds.

He et al. (2003) investigated the effect of ethanol-blended gasoline fuels (E10 and E30) and unleaded gasoline (E0) on exhaust emissions and catalyst conversion efficiencies. E10 and E30 fuels contained 10\% ethanol and $30 \%$ ethanol by volume, respectively. Engine-out emissions $\mathrm{CO}, \mathrm{THC}$, and $\mathrm{NO}_{\mathrm{x}}$ at an idle speed slightly decreased with E10; however, E30 reduced CO, THC, and $\mathrm{NO}_{\mathrm{x}}$ by $35.7 \%, 53.4 \%$, and $33 \%$ respectively. Under different loads and speeds, ethanol decreased engine-out $\mathrm{CO}$ emissions up to $5.8 \%$. At part loads, ethanol increased CO conversion at $2000 \mathrm{rpm}$, and solely E30 enhanced catalyst efficiency at $3000 \mathrm{rpm}$. CO conversion decreased at full loads. E10 and E30 significantly reduced engine-out $\mathrm{THC}$ emissions up to $29.5 \%$ at different loads and engine speeds. In general, THC conversion efficiencies of ethanol-blended fuels were lower than that of E0, but the tailpipe THC emissions of $\mathrm{E} 10$ and E30 were less. When it comes to $\mathrm{NO}_{\mathrm{x}}$, ethanol decreased engine-out emissions. The $\mathrm{NO}_{\mathrm{x}}$ conversions of $\mathrm{E} 10$ and E30 were lower than that of E0, but the tailpipe $\mathrm{NO}_{\mathrm{x}}$ emissions of the test fuels showed similar results.

Gong et al. (2011) researched the catalyst light-off behavior during engine cold start on LPG fueled SI engine. The effect of layout catalytic converter, ignition timing, and idle speed on the light-off behavior of the three-way catalytic converter was investigated in this study. The light-off time significantly decreased when the catalyst position was placed near the cylinder head. Also, delaying ignition timing resulted in a reduction in the light-off time. Additionally, when the idle speed increased from $1400 \mathrm{rpm}$ to $1800 \mathrm{rpm}$, the light-off time decreased thanks to transferring more heat to the catalytic converter.

Kwak et al. (2007) investigated the total hydrocarbon (THC) emissions during cold start duration in the liquid phase LPG injection engine. When the ignition timing was delayed from $10^{\circ} \mathrm{BTDC}$ to TDC and $10^{\circ}$ ATDC, THC emissions decreased by $23 \%$ and $31 \%$, respectively. 
Furthermore, retarding the ignition timing reduced the catalyst light-off time.

Kim et al. (2013) studied the THC and nano-particle emissions of liquid phase LPG direct injection engine in the cold start condition. Retarding the ignition timing provided an increase in converter bed temperature, a reduction in engine-out $\mathrm{HC}$ emissions, and a development of the catalyst light-off performance.

Du et al. (2020) tested light-duty gasoline vehicles at different coolant temperatures $25^{\circ} \mathrm{C}$ (cold-start), $71{ }^{\circ} \mathrm{C}$ (hot-start I), and $87{ }^{\circ} \mathrm{C}$ (hot-start II) in their study for cold-start emissions in a real driving test. The cumulative $\mathrm{CO}, \mathrm{CO}_{2}$, and PN emissions in the cold-start test were more than the emissions in the hot start-test I and II. For instance, the cumulative $\mathrm{CO}$ emissions for the cold start condition were higher up to 1.95 times and 39.3 times than the $\mathrm{CO}$ emissions in the hot-start test I and II, respectively. When it comes to the cumulative $\mathrm{NO}_{\mathrm{x}}$ emissions, they found the maximal results in the hot start test I of the cumulative $\mathrm{NO}_{\mathrm{x}}$ emissions.

Saha et al. (2020) expressed carbon monoxide, unburnt hydrocarbon, smoke, and nitrogen oxide emissions could be decreased with the help of using bio-additives in compression ignition engines.

In internal combustion engines, especially in the use of alternative fuels, the operating conditions to be determined by the optimization of power generation, fuel consumption, and exhaust emissions should be made sensitively by the engine management system (Jacob and Ashok 2020; Santos et al. 2021; Ashok et al. 2016). Cold start emissions of internal combustion engines used in conventional and hybrid vehicles will keep their importance for the ecosystem. These emissions could be improved by using alternative fuels and controlling the engine management system and after-treatment system. For this purpose, the effect of oxygenated fuels on exhaust emissions at the low ambient temperature startup and warm-up operation of the SI engine was investigated. It does not require any modifications to the engine when using gasoline/alcohol mixtures containing low amounts of alcohol (Murachman et al. 2014), so ethanol and methanol (10\% by vol.) were used as alternative fuels. Moreover, the catalyst efficiency was examined in hot and cold situations of the catalytic converter for the same operating of the engine.

\section{MATERIALS AND METHOD}

The schematic diagram of the experimental equipment and the test engine can be seen in Fig. 1. The test engine was a four-stroke, multi-point fuel injection, in-line four cylinders, double overhead camshaft, and $1.6 \mathrm{~L}$ sparkignition engine. Also, the test engine was equipped with a three-way catalyst and secondary air injection system. In all tests, the secondary air injection system was disabled so that it would not affect the results. The engine's technical specifications are given in Table 1.

Table 1. Technical specifications of the test engine.

\begin{tabular}{l|c}
\hline Item & Specification \\
\hline Engine & $\begin{array}{c}\text { Ford 1.6 L MVH 416 } \\
\text { DOHC 16V }\end{array}$ \\
\hline Engine type & Four-stroke, SI engine \\
\hline Cylinder bore X stroke & 76 X $88 \mathrm{~mm}$ \\
\hline Stroke volume & $1597 \mathrm{cc}$ \\
\hline Compression ratio & $10.3: 1$ \\
\hline Firing order & $1-3-4-2$ \\
\hline Idle speed & $900 \pm 50 \mathrm{rpm}$ \\
\hline Maximum torque & $138 \mathrm{Nm}$ at $3500 \mathrm{rpm}$ \\
\hline Maximum power output & $66 \mathrm{~kW}$ at $5250 \mathrm{rpm}$ \\
\hline
\end{tabular}

The experiments were performed at $6-10{ }^{\circ} \mathrm{C}$ ambient temperatures. The engine idle speed and mixture formation were controlled by the engine control unit during the whole test. In addition, unleaded gasoline and unleaded gasoline/alcohol blended fuels were used in the experiments. Unleaded gasoline/alcohol blended fuels

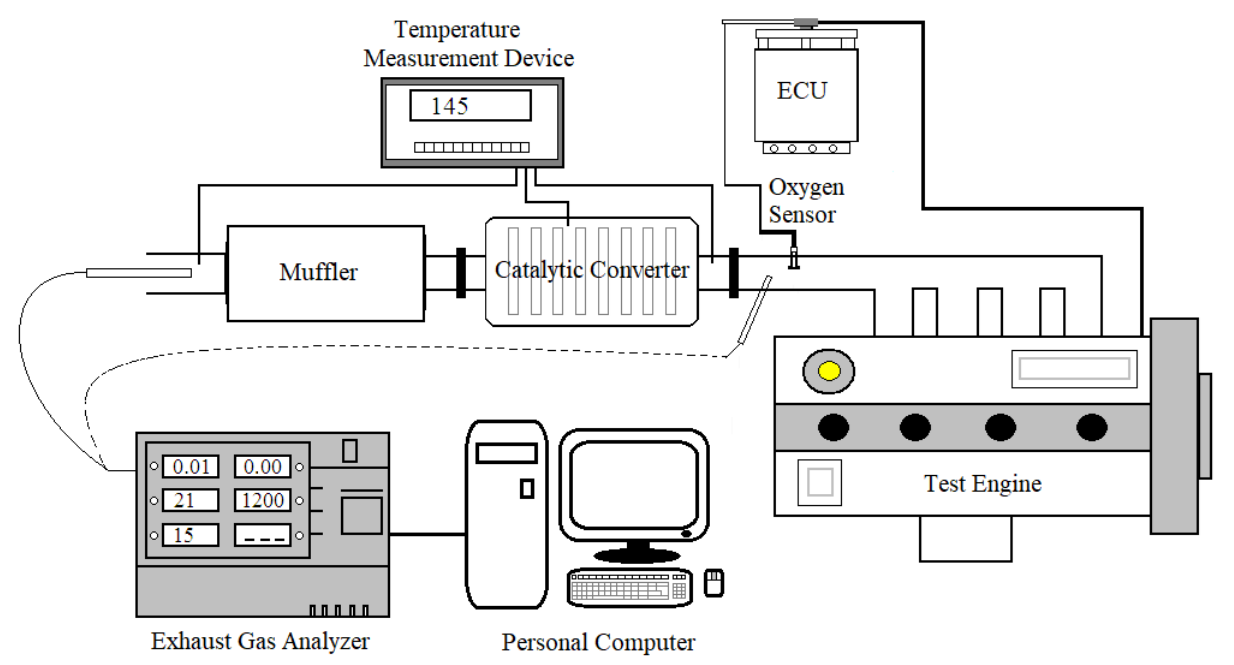

Figure 1. The test engine and the experimental equipment. 
were M10 and E10. Unleaded gasoline/methanol blend which was called M10 contained $10 \%$ methanol vol.\% in the blend. Also, E10 (unleaded gasoline/ethanol blend) had $10 \%$ ethanol vol. $\%$. Methanol and ethanol used in the blends had $99.5 \%$ purity. Some properties of the unleaded gasoline and alcohol blended fuels are summarized in Table 2.

Table 2. Properties of test fuels.

\begin{tabular}{l|c|c|c}
\hline Property items & M10 & E10 & UG \\
\hline Density $\left(\mathrm{kg} / \mathrm{m}^{3}\right.$ at $\left.15^{\circ} \mathrm{C}\right)$ & 774 & 773.7 & 772.9 \\
\hline RVP $(\mathrm{kPa})$ & 75.1 & 59.7 & 51.9 \\
\hline Distillation (vol.\%) & & & \\
$\quad 70^{\circ} \mathrm{C}$ & 38.5 & 35.3 & 18.7 \\
$\quad 100^{\circ} \mathrm{C}$ & 46.1 & 49.3 & 41.4 \\
$\quad 150^{\circ} \mathrm{C}$ & 88.8 & 89.1 & 87.6 \\
\hline RON & & 98.3 & 96.1 \\
\hline MON & & & 85.8 \\
\hline
\end{tabular}

Elimko-6000 which was a 12-channel temperature measurement device with $\pm 1{ }^{\circ} \mathrm{C}$ sensitivity and $\mathrm{NiCr}-\mathrm{Ni}$ thermocouples were used for measuring the ambient temperature, exhaust temperature, catalyst inlet, and outlet temperatures. Temperatures were also measured with DT-8859 a non-contact infrared thermometer with $\pm 2^{\circ} \mathrm{C}$ accuracy. The exhaust emissions were analyzed by Sun Gas Analyzer MGA 1500s. The exhaust gas analyzer was calibrated before the experiments. Samples of the exhaust gas were taken before and after the catalyst (engine-out and tailpipe emissions) by sample probe. Table 3 shows the technical specifications and measurement accuracies of Sun Gas Analyzer MGA 1500s. In the experiments, the measured data were stored on the personal computer via RS-232 port.

Table 3. Technical specifications of exhaust gas analyzer (MGA 1500S).

\begin{tabular}{l|c|c}
\hline $\begin{array}{c}\text { Measured } \\
\text { Quantity }\end{array}$ & $\begin{array}{c}\text { Measurements } \\
\text { Range/Resolution }\end{array}$ & $\begin{array}{c}\text { Accuracy } \\
\text { Relative/Absolute }\end{array}$ \\
\hline $\mathrm{CO}$ & $0-14 \%$ vol. & $\pm 5 \% / \pm 0.03$ \\
\hline $\mathrm{CO}_{2}$ & $0-18 \%$ vol. & $\pm 5 \% / \pm 0.5$ \\
\hline $\mathrm{HC}$ & $\begin{array}{c}0-2000 \mathrm{ppm} \text { vol. } \\
2000-5000 \mathrm{ppm} \text { vol. } \\
5000-9999 \mathrm{ppm} \text { vol. }\end{array}$ & $\begin{array}{c} \pm 5 \% / 10 \mathrm{ppm} \\
\pm 5 \% \\
\pm 10 \%\end{array}$ \\
\hline $\mathrm{O}_{2}$ & $0-25 \%$ vol. & $\pm 5 \% / \pm 0.1$ \\
\hline $\mathrm{NO}$ & $0-5000 \mathrm{ppm}$ vol. & $\pm 5 \% / \pm 25 \mathrm{ppm}$ vol. \\
\hline Engine speed & $0-9999 \mathrm{rpm}$ & $\pm 0.5 \%$ \\
\hline AFR & $\begin{array}{c}5.00-50.00 \\
\text { (calculated) }\end{array}$ \\
\hline Lambda $(\lambda)$ & $\begin{array}{c}0.000-4.000 \\
\text { (calculated) }\end{array}$ \\
\hline
\end{tabular}

\section{RESULTS AND DISCUSSION}

The Effects of the Engine Running Condition and Alternative Fuels on Pollutants Emissions

In the experiments, idle speed and air/fuel ratio were controlled by the engine's ECU. Fig. 2 shows the change in engine idle speed during the engine's running period.
Furthermore, the variation in the relative air-fuel ratio during the test is shown in Fig. 3. The idle speed should be increased in order to shorten the engine's warm-up duration. Also, fuel enrichment is necessary to provide smooth engine running. Therefore, in fuel injection systems, the electronic control unit regulates both the idle speed and the air/fuel ratio according to the engine operating temperature. As the engine reaches normal operating temperature, the idling speed and fuel enrichment are reduced to their rated values. In each experiment, as shown in Fig. 2, the idle speed varied similarly for every test fuel. The idle speed was high at the beginning and decreased as the engine heated up. Fig. 2 shows that the idle speed reaches its nominal value approximately 450 seconds later and does not change significantly.

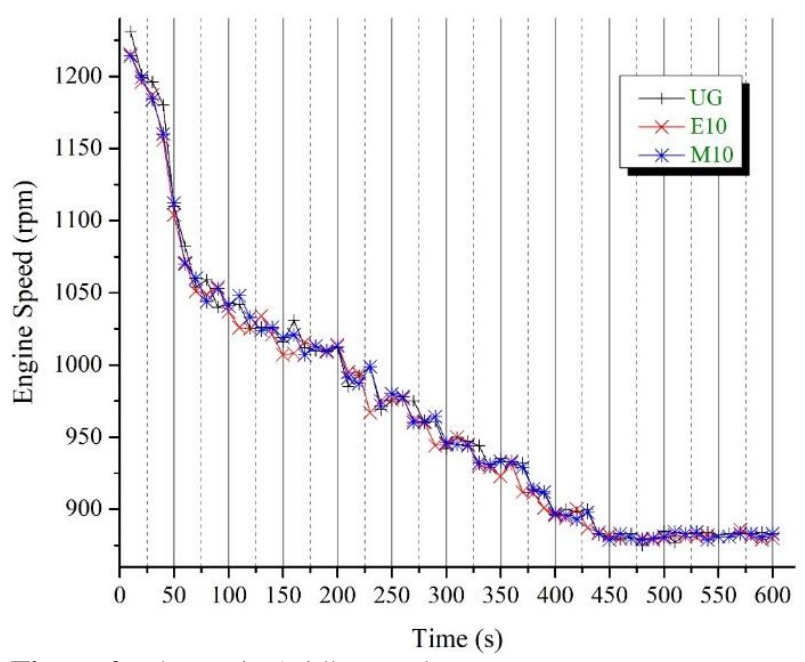

Figure 2. The engine's idle speed.

As at idle speed, the relative air-fuel ratio varied according to the engine's running conditions. At the beginning of the experiments, the mixture was rich and later became poor when the engine reached the nominal running condition. Moreover, the relative air-fuel ratio in alcohol fuels that contain oxygen is poorer. The leaning effect of alcohol fuels (Hsieh et al. 2002; Al-Hasan 2003; Guerrieri et al. 1995; Elfasakhany 2016; Sivasubramanian et al. 2017) leads to an increase in the relative air-fuel ratio. The relative air-fuel ratio $(\lambda)$ is defined in Eq. (1).

$$
\lambda=\frac{A F R_{\text {actual }}}{A F R_{\text {stoich }}}
$$

The stoichiometric air/fuel ratio of alcohol blended fuels (E10 and M10) is lower than unleaded gasoline. Also, they can provide more oxygen to the combustion. As a result, if the original fuel injection strategy does not change, a leaner mixture will be obtained in oxygenated fuels. 


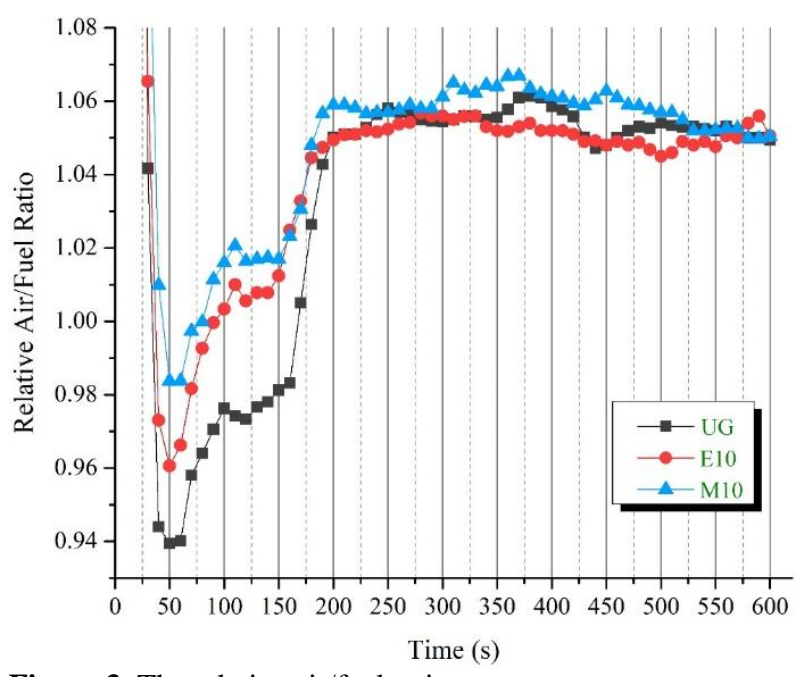

Figure 3. The relative air/fuel ratio.

When the engine is running at low ambient temperature, $\mathrm{CO}$ and $\mathrm{HC}$ emissions are high until the cylinder walls heat up and the air/fuel ratio rises to the nominal value (Iodice et al. 2018). A similar situation can be seen in the variation of $\mathrm{CO}$ emission at the engine start-up and its operation within 600 seconds given in Fig. 4. In addition, alcohol blended fuels appear to be effective on $\mathrm{CO}$ emission. Similar results were also obtained in the literature (He et al. 2003; Hsieh et al. 2002; Al-Hasan 2003; Zhao et al. 2011; Keskin and Gürü 2011; Elfasakhany 2015; Saraswat and Chauhan 2020; Badrawada and Susastriawan 2019). The leaning effect or in other words the oxygen presence of blended fuels enhances the combustion efficiency and supports lower $\mathrm{CO}$ emission before the catalyst. The leaning effect of blended fuels supports lower $\mathrm{CO}$ emission before the catalyst. Especially in the initial about 150 seconds, the effect of alcohol blended fuels on CO emission is clear. This may be due to the control strategy of the engine management system. Similarly, it can be seen in Fig. 3 that there is no remarkable variation in the relative air/fuel ratio after the last 450 seconds of the test. CO emission influences mainly by the air/fuel ratio.

To meet the emissions regulations, current fuel injection systems adjust the air-fuel mixture by operating a closedloop control strategy. For this purpose, a lambda sensor is used to provide feedback data to the electronic control unit. This sensor operates reliably after reaching an adequate temperature (about $300{ }^{\circ} \mathrm{C}$ ) and measures the amount of oxygen in the exhaust gas. The oxygen content in the exhaust gas is a result of the lambda setting of the engine management system (Denton 2000; Schäfer and Basshuysen 1995).

Compared to the data obtained in 150 seconds, CO emissions before catalytic convertor (engine-out $\mathrm{CO}$ emissions) decreased by an average of $34.5 \%$ E10 fuel and $44.8 \%$ M10 fuel compared to the unleaded gasoline. In the last 450 seconds of the test, $\mathrm{CO}$ emissions decreased by an average of $8.7 \%$ and $26.4 \%$ with $\mathrm{E} 10$ and M10, respectively. A similar change in $\mathrm{CO}$ emissions was also seen in the tailpipe (after the catalytic converter). However, there was no significant reduction in $\mathrm{CO}$ emissions after the catalytic converter.
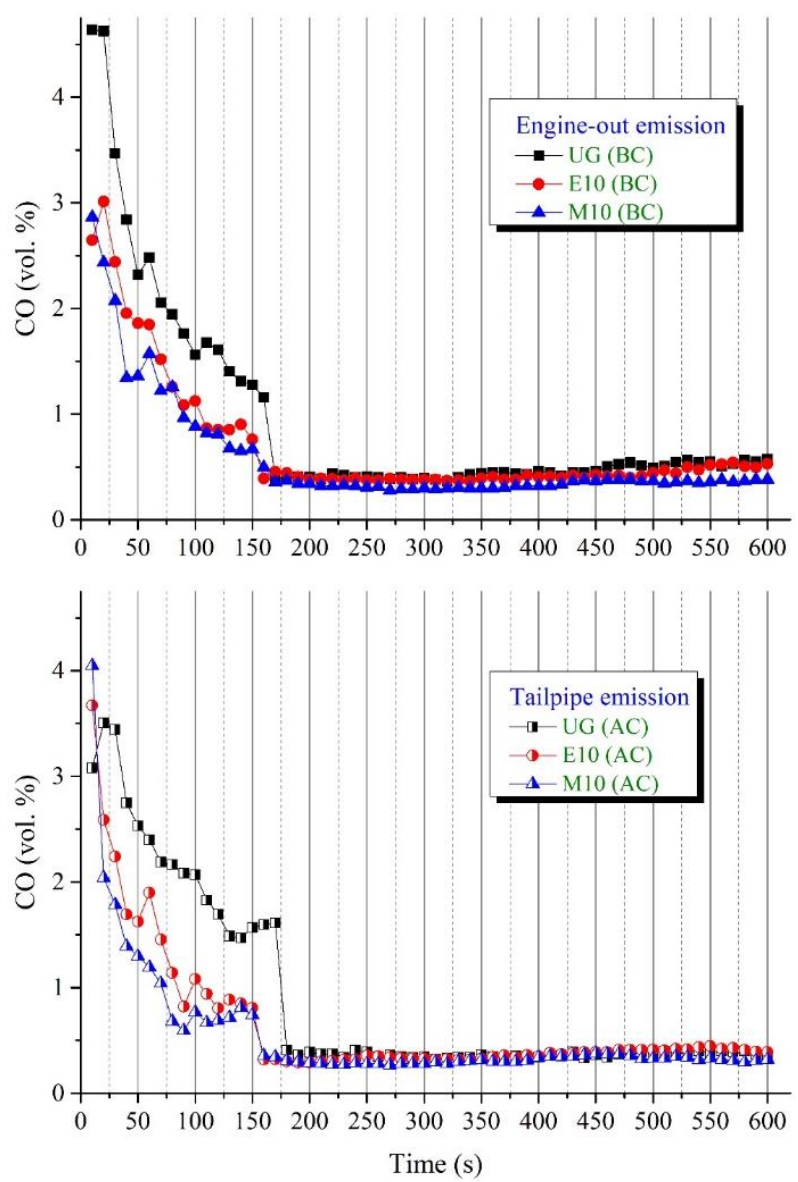

Figure 4. The $\mathrm{CO}$ emissions.

Fig. 5 presents the variation of hydrocarbon emissions for the cold start situation. Engine-out HC emissions for the oxygenated blends were obtained lower compared to the unleaded gasoline. Initial 150 seconds, an average of $23.2 \%$ E10 fuel and 25\% M10 reduction was obtained in $\mathrm{HC}$. Similar to $\mathrm{CO}$ emissions, the variation of the $\mathrm{HC}$ emissions in the last 450 seconds of the test, may be caused by the control strategy of the engine management system. Considering the whole test time, engine-out HC emissions for E10 and M10 fuels were approximately $17 \%$ lower compared to the unleaded gasoline. It is reported in the literature (Wu et al. 2004; Schifter et al. 2004; Iodice et al. 2018; Varol et al. 2014) that alternative fuels containing oxygen have a similar effect on $\mathrm{HC}$ emissions. Also, it is found that the addition of methanol to gasoline contributes to a decrease in $\mathrm{CO}$ and $\mathrm{HC}$ emissions, and improves the cold start of an SI engine in the study of Shenghua et al. (2007). Similar to the variations of $\mathrm{CO}$ emissions, there was no significant reduction in tailpipe $\mathrm{HC}$ emissions. 

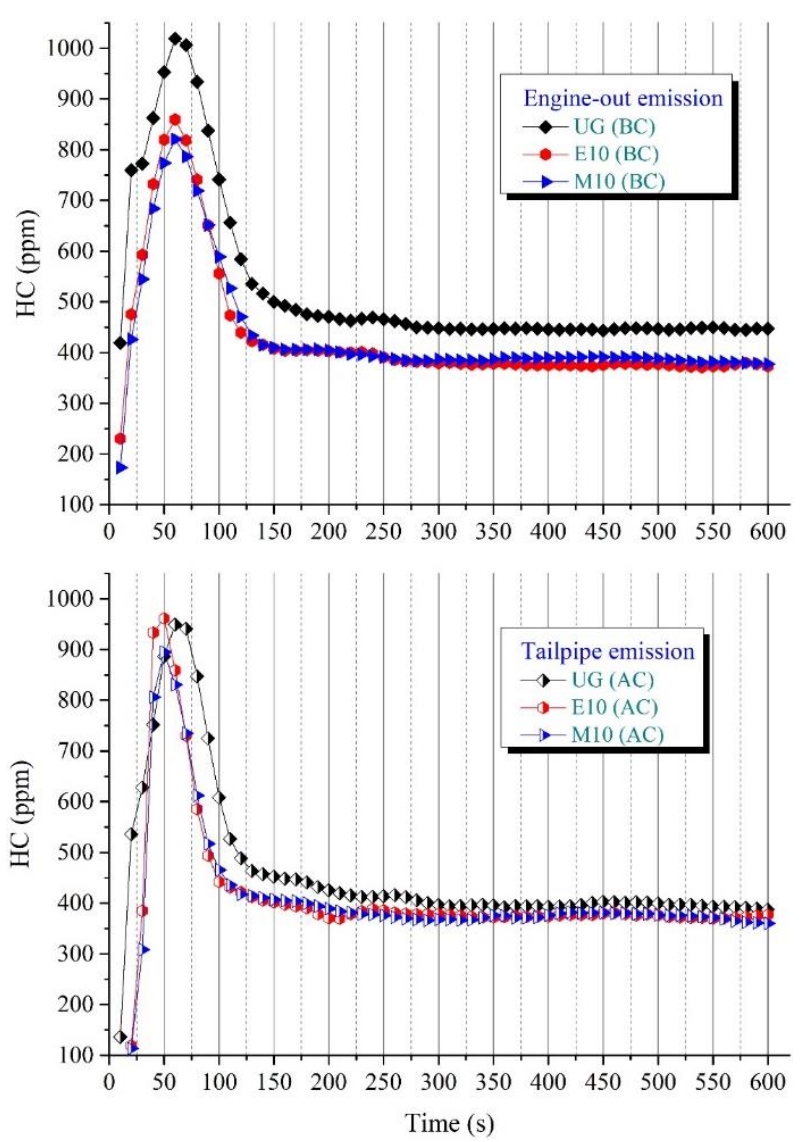

Figure 5. The HC emissions.

In the cold start and warm-up period, engine out and tailpipe NO emissions are illustrated in Fig. 6. Depending on fuel type, there are not notable variances in the engineout NO emissions. It might be due to rich air/fuel ratios and lower combustion temperatures in cold conditions. Similar to the variations of the $\mathrm{CO}$ and $\mathrm{HC}$ emissions, there is no reduction in the tailpipe $\mathrm{NO}$ emissions during 600 seconds compared to the engine-out NO.

Fig. 7 shows the variation of the exhaust gas temperature before the catalyst during the test duration. As shown in the figure, the temperature before the converter is insufficient to obtain catalyst light-off temperature. Therefore, the catalytic converter cannot be effective in this running condition. A similar experimental result was obtained by Gritsuk et al. (2018). The temperature of the catalytic converter in an idling mode was below $450 \mathrm{~K}$ in their study.

The catalyst temperature is insufficient to convert the emissions for cold start-up and warming operation, which gives rise to a high concentration of pollutant emissions in the tailpipe. In order to reduce cold-start emissions especially $\mathrm{CO}$ and $\mathrm{HC}$ emissions, the catalyst temperature must quickly reach to the light-off temperature. To achieve this, the catalyst can be positioned closer to the engine, or a pre-catalyst can be used. Retarding ignition timing or raising idle speed or electrically or chemically heated catalyst can be used, too (Bhattacharyya and Das 1999; Koltsakis and Stamatelos 1997; Shen et al. 1999; Murphy et al. 1999; Favez et al. 2009; Gao et al. 2019).
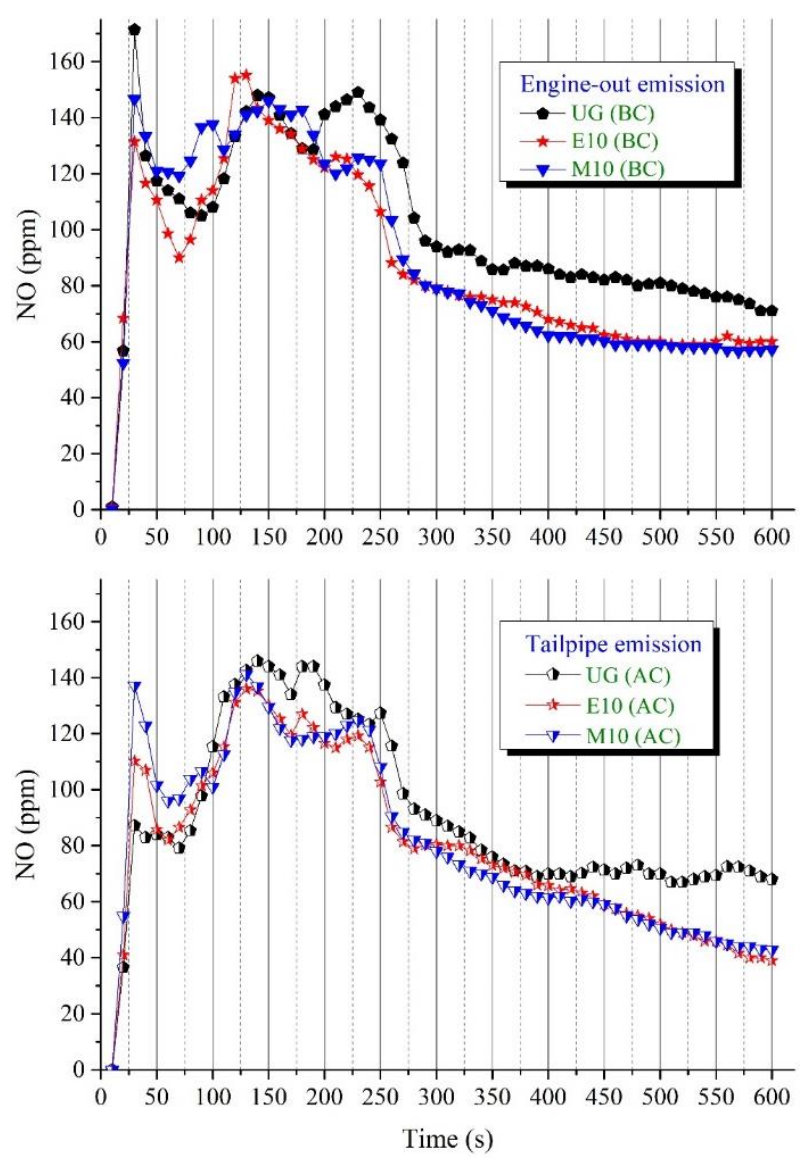

Figure 6. The NO emissions.

Gritsuk et al. (2018) emphasize that additional heating of the engine and catalytic converter improves fuel economy and exhaust emissions. Also, it is represented that fuel consumption, $\mathrm{CO}, \mathrm{HC}$, and nitrogen oxides emissions are reduced in an idling mode by $32.7 \%$, $59.6 \%, 56.1 \%$, and 93.5 , respectively.

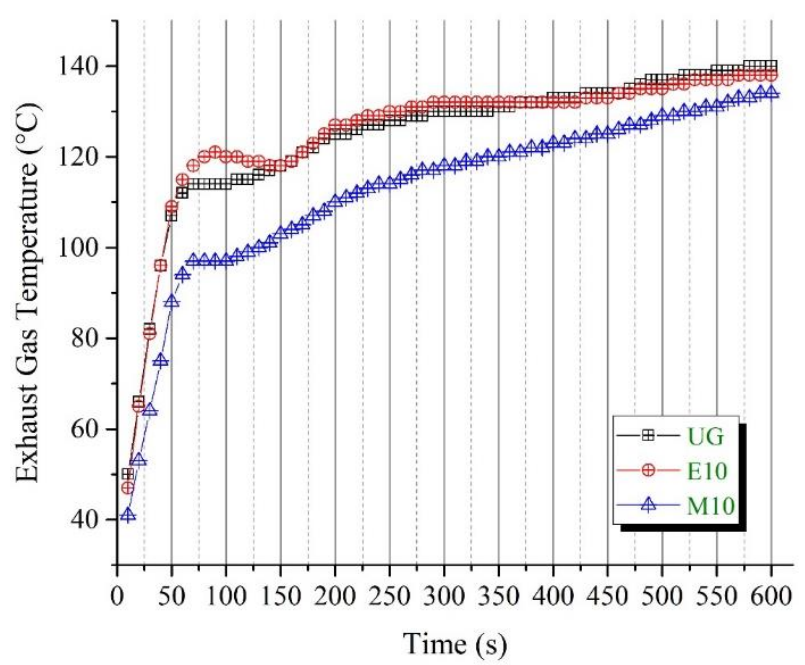

Figure 7. Exhaust gas temperature before the catalytic converter in idling operation. 
The Effects of the Hot Converter on Pollutants Emissions under the Same Engine Running Condition

To observe the effect of the hot converter on the emissions, the catalyst was heated up to $200 \pm 10^{\circ} \mathrm{C}$ of its surface by an external source. Furthermore, to achieve this aim, the experiments were reperformed under the same operating conditions as the hot converter.

Fig. 8 shows the conversion efficiencies of the $\mathrm{CO}, \mathrm{HC}$, and $\mathrm{NO}$ emissions. Catalyst efficiency for $\mathrm{CO}, \mathrm{HC}$, and NO emissions was calculated by Eq. (2). The catalyst efficiency is determined as

$$
\eta_{c}=\left(1-\frac{\text { Exhaust emission }_{\text {out }}}{\text { Exhaust emission }_{\text {in }}}\right) \cdot 100 \%
$$

where exhaust emission $_{\text {in }}$ and exhaust emission out $_{\text {are the }}$ concentration of the $\mathrm{CO}$ or $\mathrm{HC}$ or $\mathrm{NO}$ emissions at the catalyst inlet and outlet, respectively.
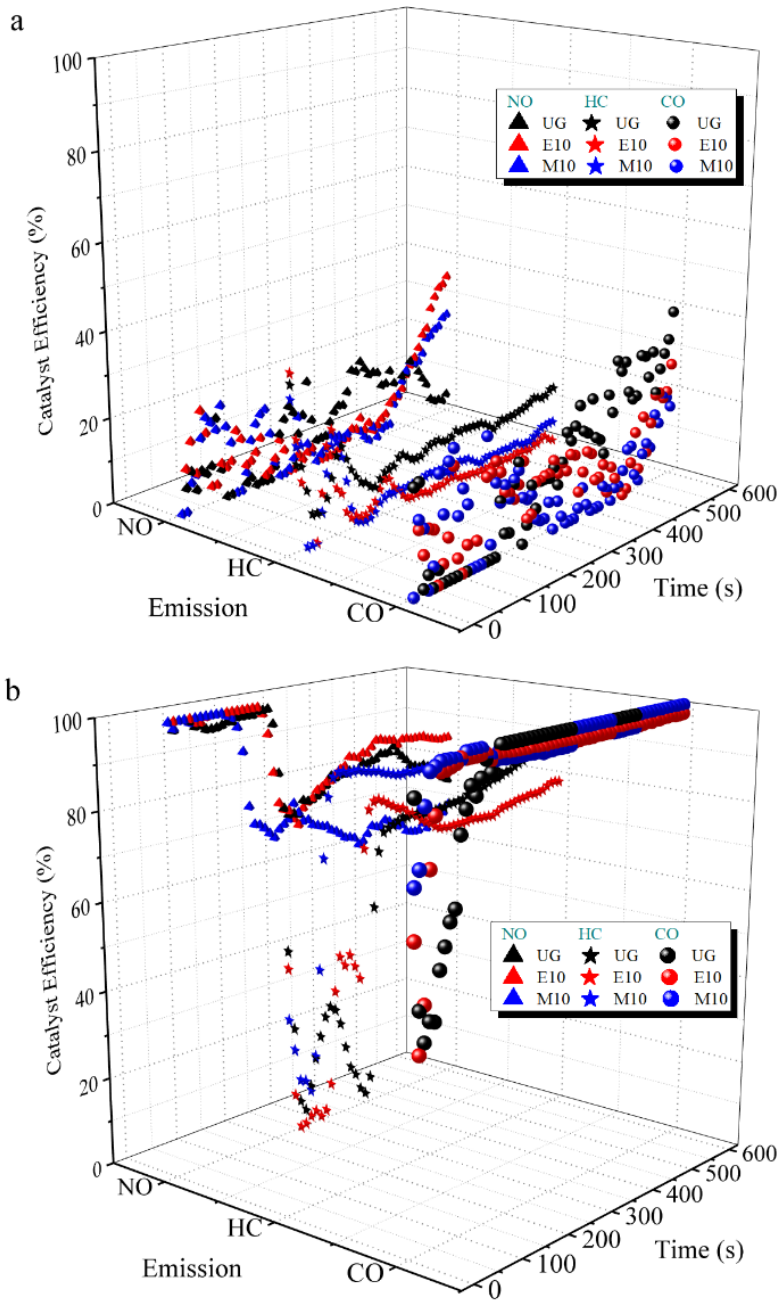

Figure 8. The conversion efficiencies of the catalytic converter for CO, HC, and NO: a Normal warm-up test condition b Hot catalyst test condition

Fig. 8a presents the conversion efficiencies which were obtained from the previous experimental results. As seen in the figure, if the converter cannot reach light-off temperature, the efficiencies are below $50 \%$. Because of this reason, no remarkable difference in engine output and tailpipe emissions of pollutants occurred in the previous experiments.

However, tailpipe emissions especially $\mathrm{CO}$ can be zero if the converter is sufficiently heated. Although the engine is cold, the preheated converter can increase the efficiency by up to $100 \%$ as seen in Fig. 8b. In the literature, Gong et al. (2011) point out that as the catalyst temperature rises, the catalyst light-off time decreases, and conversion efficiency increases. Besides, Mianzarasvand et al. (2017) express that the temporary and permanent heating of the catalytic converter is efficient in decreasing $\mathrm{CO}$ emission especially in the first $30 \mathrm{~s}$ of the cold start and warm-up period of the motorcycle engine. Furthermore, Shen et al. (1999) emphasize that the tailpipe $\mathrm{CO}$ emission decreases sharply when the initial converter temperature rises to $600 \mathrm{~K}$ or higher.

With regard to the catalyst's efficiency for $\mathrm{HC}$ conversion, as seen in Fig. 8b, when the converter was heated, the $\mathrm{HC}$ emission after the catalytic converter outlet was significantly reduced and the efficiency reached $90 \%$. It was obtained that $\mathrm{HC}$ conversion efficiency was less than CO. For a similar result, Mahadevan and Subramanian (2017) express in their study that the light-off temperature of $\mathrm{HC}$ is higher than $\mathrm{CO}$ due to more activation energy requirement of hydrocarbon. Also, Shen et al. (1999) express that when the initial catalyst temperature is $600 \mathrm{~K}$ or beyond, the tailpipe $\mathrm{HC}$ emissions reduce enormously. Moreover, it is emphasized that contrary to the $\mathrm{CO}$ emission, $\mathrm{HC}$ emission decrease continuously as the initial catalyst temperature is increased over $600 \mathrm{~K}$.

Catalyst's efficiency for NO emission was obtained similar to $\mathrm{CO}$ and $\mathrm{HC}$ conversion efficiencies. If the converter is hot enough, even the engine is cold, the NO conversion efficiency is not affected, and NO emission decreases significantly.

Tailpipe CO, HC, and NO emissions for hot catalyst are shown in Fig. 9. Especially the effect of oxygenated blends on pollutants is more apparent for $\mathrm{CO}$ and $\mathrm{HC}$ emissions before 150 and 200 seconds respectively, and they are lower than unleaded gasoline based on the leaning effect. It is seen in the figure, NO emission decreases sharply in the situation for the hot catalyst. After approximately 200 seconds, the NO increases slightly for all test fuels. This is probably because the engine is running lower than the stoichiometric air/fuel ratio. 

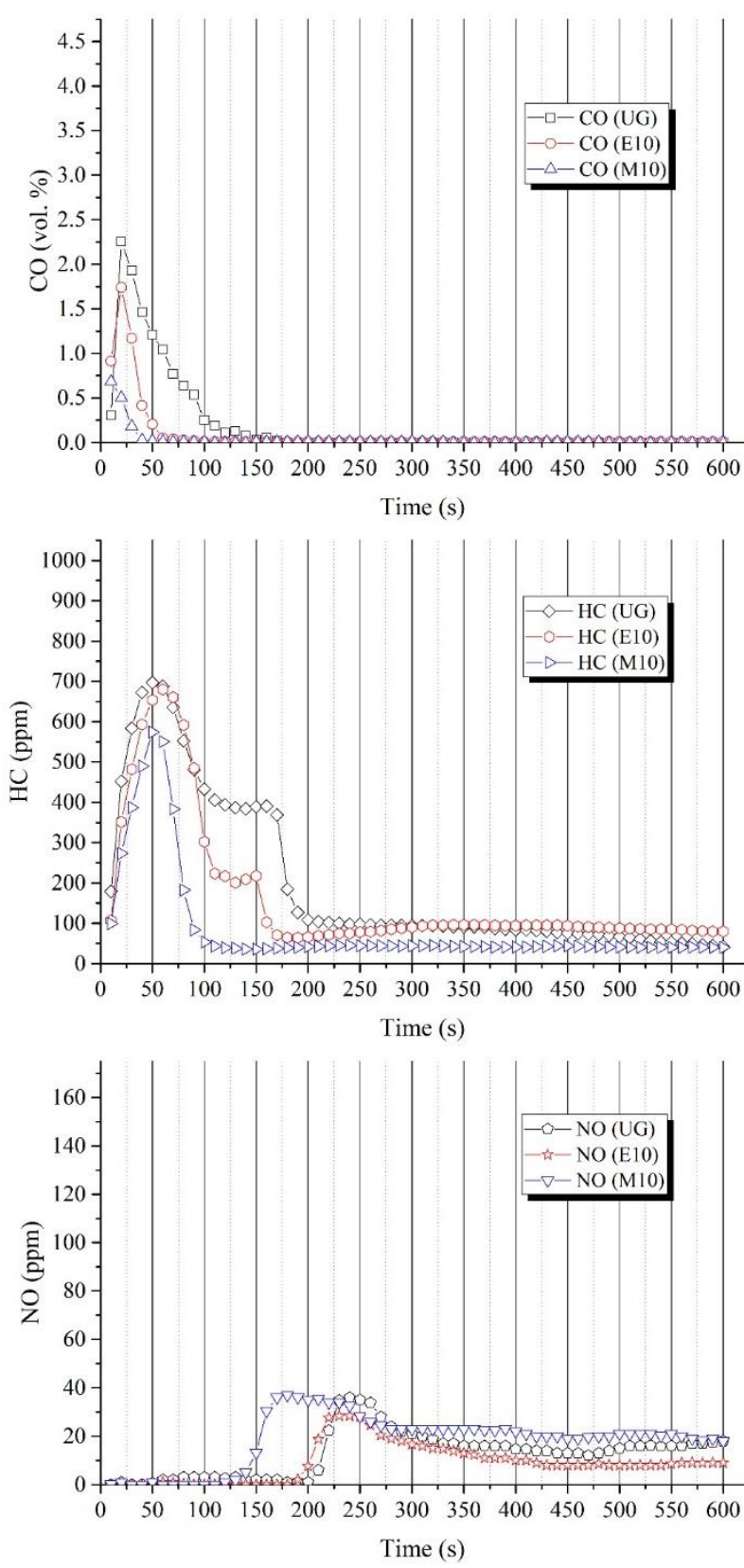

Figure 9. Tailpipe emissions for hot catalyst test condition

\section{CONCLUSIONS}

The effects of oxygenated fuels and hot catalytic converter on pollutants and catalyst conversion efficiency start-up and warm-up operation of the SI engine at the low ambient temperature have been investigated in the present work.

In general, the effect of E10 and M10 fuels on the improvement of $\mathrm{CO}$ emissions is clearer than $\mathrm{HC}$ emissions. Engine-out $\mathrm{CO}$ emissions decreased for alcohol blended fuels because of the leaning effect. It reduced by $34.5 \%$ for E10 fuel and $44.8 \%$ for M10 fuel compared to the unleaded gasoline in the first 150 seconds. Towards the end of the test, the difference between alcohol blends and unleaded gasoline was less. Similar results were obtained in HC. Engine output HC emissions were achieved approximately $25 \%$ lower for E10 and M10 fuels than for unleaded gasoline. When it comes to the engine-out $\mathrm{NO}$ emissions, no significant variances were observed depending on fuel type.

As the engine heats up, essentially there are no remarkable differences among test fuels compared to the variations at the beginning of the experiments.

It was found that the catalytic converter did not reach the light-off temperature when the engine ran at the cold start and warm-up period without preheating the catalyst. The idling of the engine was not enough to warm up the converter. As a result of this, there were no significant reductions in the pollutants between engine-out and tailpipe.

If the converter is preheated, tailpipe $\mathrm{CO}$ emission can be zero and the efficiency of $\mathrm{CO}$ conversion can reach $100 \%$.

For the hot catalyst test condition, $\mathrm{HC}$ emission after the catalyst was significantly reduced and the efficiency reached $90 \%$. Moreover, variations in NO emissions were similar to $\mathrm{CO}$ and $\mathrm{HC}$ emissions. Also, the air/fuel ratio might have affected the NO conversion efficiency.

In conventional and hybrid vehicles, studies on engine management and emission control systems to decrease emissions during the cold start and the warm-up process of internal combustion engines will keep their importance for the environment and human health.

\section{REFERENCES}

Abdel-Rahman A.A., 1998, On the emissions from internal-combustion engines: A review, International Journal of Energy Research, 22 (6), 483-513. doi: 10.1002/(SICI)1099-114X(199805)22:6<483::AIDER377>3.0.CO;2-Z

Al-Hasan M., 2003, Effect of ethanol-unleaded gasoline blends on engine performance and exhaust emission, Energy Conversion and Management, 44 (9), 1547-1561. doi: 10.1016/S0196-8904(02)00166-8

Arce-Alejandro R., Villegas-Alcaraz J.F., GómezCastro, F.I., Juárez-Trujillo L., Sánchez-Ramírez E., Carrera-Rodríguez M., Morales-Rodríguez R., 2018, Performance of a gasoline engine powered by a mixture of ethanol and n-butanol, Clean Technologies and Environmental Policy, 20, 1929-1937.

doi: 10.1007/s10098-018-1584-5

Ashok B., Ashok S.D., Kumar C.R., 2016, A review on control system architecture of a SI engine management system, Annual Reviews in Control, 41, 94-118.

doi: 10.1016/j.arcontrol.2016.04.005

Badrawada I.G.G., Susastriawan A.A.P., 2019, Influence of ethanol-gasoline blend on performance and emission of four-stroke spark ignition motorcycle, Clean Technologies and Environmental Policy, 21, 1891-1896. doi: 10.1007/s10098-019-01725-w 
Baskar P., Senthilkumar A., 2016, Effects of oxygen enriched combustion on pollution and performance characteristics of a diesel engine, Int. J. Eng. Sci. Technol., 19 (1), 438-443. doi: 10.1016/j.jestch.2015.08.011

Bechtold R.L., 1997, Alternative Fuels Guidebook, Society of Automotive Engineers Inc., Warrendale.

Bhattacharyya S., Das R.K., 1999, Catalytic control of automotive $\mathrm{NO}_{\mathrm{x}}$ : A review, International Journal of Energy Research, 23 (4), 351-369. doi: 10.1002/(SICI)1099-114X(19990325)23:4<351::AIDER497>3.0.CO;2-T

Çelikten İ., Karaaslan E., Solmaz H., Okur M., Polat S., 2015, Experimental investigation of the effects of gasoline additives on engine performance and exhaust emissions, Journal of Thermal Sciences and Technology, 35 (1), 87-95. (In Turkish)

Datta A., Mandal B.K., 2017, A numerical study on the performance, combustion and emission parameters of a compression ignition engine fuelled with diesel, palm stearin biodiesel and alcohol blends, Clean Technologies and Environmental Policy, 19, 157-173. doi: 10.1007/s10098-016-1202-3

Denton T., 2000, Automobile Electrical and Electronic Systems, Society of Automotive Engineers Inc., Warrendale.

Du B., Zhang L., Geng Y., Zhang Y., Xu H., Xiang G., 2020, Testing and evaluation of cold-start emissions in a real driving emissions test, Transportation Research Part D: Transport and Environment, 86, 102447. doi:10.1016/j.trd.2020.102447

Elfasakhany A., 2015, Investigations on the effects of ethanol-methanol-gasoline blends in a spark-ignition engine: Performance and emissions analysis, Int. J. Eng.

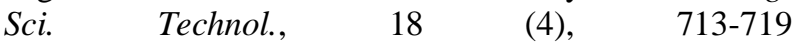
doi:10.1016/j.jestch.2015.05.003

Elfasakhany A., 2016, Performance and emissions of spark-ignition engine using ethanol-methanol-gasoline, n-butanol-iso-butanol-gasoline and iso-butanolethanol-gasoline blends: A comparative study, Int. J. Eng. Sci. Technol., 19 (4), 2053-2059. doi: 10.1016/j.jestch.2016.09.009

Favez, J.Y., Weilenmann M., Stilli J., 2009, Cold start extra emissions as a function of engine stop time: Evolution over the last 10 years, Atmospheric Environment, 43 (5), 996-1007. doi: 10.1016/j.atmosenv.2008.03.037

Gao J., Tian G., Sorniotti A., Karci A.E., Palo R.D., 2019, Review of thermal management of catalytic converters to decrease engine emissions during cold start and warm up, Applied Thermal Engineering, 147, 177187. doi: 10.1016/j.applthermaleng.2018.10.037
Gong C., Huang K., Deng B., Liu X., 2011, Catalyst light-off behavior of a spark-ignition LPG (liquefied petroleum gas) engine during cold start, Energy, 36 (1), 53-59. doi.org/10.1016/j.energy.2010.11.026

Gritsuk I.V., Mateichyk V., Tsiuman M., Gutarevych Y., Smieszek M., Goridko N., 2018, Reducing harmful emissions of the vehicular engine by rapid after-start heating of the catalytic converter using thermal accumulator, SAE Technical Paper, 2018-01-0784 ISSN 0148-7191. doi: 10.4271/2018-01-0784

Guerrieri D.A., Caffrey P.J., Rao V., 1995, Investigation into the vehicle exhaust emissions of high percentage ethanol blends, SAE Technical Paper, 950777 ISSN 0148-7191. doi: 10.4271/950777

He B.Q., Wang J.X., Hao J.M., Yan X.G., Xiao J.H., 2003, A study on emission characteristics of an EFI engine with ethanol blended gasoline fuels, Atmospheric Environment, 37 (7), 949-957. doi: 10.1016/S13522310(02)00973-1

Heywood J.B., 1998, Internal Combustion Engine Fundamentals, McGraw-Hill Inc., New York.

Hochgreb S., 1998, Combustion-Related Emissions in SI Engines (Chapter 6) in: Sher E. (Ed.) Handbook of Air Pollution from Internal Combustion Engines Pollutant Formation and Control, Academic Press., pp. 118-170 Boston.

Hsieh W.D., Chen R.H., Wu T.L., Lin T.H., 2002, Engine performance and pollutant emission of an SI engine using ethanol-gasoline blended fuels, Atmospheric Environment, 36 (3), 403-410. doi.org/10.1016/S13522310(01)00508-8

Iodice P., Langella G., Amoresano A., 2018, Ethanol in gasoline fuel blends: Effect on fuel consumption and engine out emissions of SI engines in cold operating conditions, Applied Thermal Engineering, 130, 10811089. doi: 10.1016/j.applthermaleng.2017.11.090

Jacob A., Ashok B., 2020, An interdisciplinary review on calibration strategies of engine management system for diverse alternative fuels in IC engine applications, Fuel, 278, 118236. doi.org/10.1016/j.fuel.2020.118236

Keskin A., Gürü M., 2011, The effects of ethanol and propanol additions into unleaded gasoline on exhaust and noise emissions of a spark ignition engine, Energy Sources, Part A: Recovery, Utilization, and Environmental Effects, 33 (23), 2194-2205. doi: $10.1080 / 15567030903530558$

Kim J., Choi K., Myung C.L., Park S., 2013, Experimental evaluation of engine control strategy on the time resolved THC and nano-particle emission characteristics of liquid phase LPG direct injection (LPG-DI) engine during the cold start, Fuel Processing 
Technology,

106 ,

$166-173$

doi.org/10.1016/j.fuproc.2012.07.020

Koltsakis G.C., Stamatelos A.M., 1997, Catalytic automotive exhaust aftertreatment, Progress in Energy and Combustion Science, 23 (1), 1-39 doi:10.1016/S0360-1285(97)00003-8

Kwak H., Myung C.L., Park S., 2007, Experimental investigation on the time resolved THC emission characteristics of liquid phase LPG injection (LPLi) engine during cold start, Fuel, 86 (10-11), 1475-1482. doi.org/10.1016/j.fuel.2006.11.023

Mahadevan G., Subramanian S., 2017, Experimental Investigation of cold start emission using dynamic catalytic converter with pre-catalyst and hot air injector on a multi cylinder spark ignition engine, SAE Technical Paper, 2017-01-2367 ISSN 0148-7191. doi:10.4271/2017-01-2367

MGA 1500S Modular Gas Analyser, 2001, Operator's Manual, Snap-on Europe Holding B.V., Amsterdam.

Mianzarasvand F., Shirneshan A., Afrand M., 2017, Effect of electrically heated catalytic converter on emission characteristic of a motorcycle engine in coldstart conditions: CFD simulation and kinetic study, Applied Thermal Engineering, 127, 453-464. doi.org/10.1016/j.applthermaleng.2017.07.180

Mills G.A., Ecklund E.E., 1987, Alcohols as components of transportation fuels, Ann. Rev. Energy, 12, 47-80.

Mondt J.R., 2000, Cleaner Cars: The History and Technology of Emission Control since the 1960s, Society of Automotive Engineers Inc., Warrendale.

Murachman B., Pranantyo D., Putra E.S., 2014, Study of gasohol as alternative fuel for gasoline substitution: Characteristics and performances, Int. Journal of Renewable Energy Development, 3 (3), 175-183. doi.org/10.14710/ijred.3.3.175-183

Murphy O.J., Kukreja R.T., Andrews C.C., 1999, Electrically initiated chemically heated catalytic converter to reduce cold-start emissions from automobiles, SAE Technical Paper, 1999-01-1233 ISSN 0148-7191. doi: 10.4271/1999-01-1233

Nabi M.N., Rasul M.G., Brown R.J., 2020, Notable reductions in blow-by and particle emissions during cold and hot start operations from a turbocharged diesel engine using oxygenated fuels, Fuel Processing Technology, 203, 106394 doi.org/10.1016/j.fuproc.2020.106394

Saha D., Sinha A., Roy B., 2020, A critical review of emission and performance characteristics of CI engine using bio-additives, Clean Technologies and Environmental Policy, 22, 1613-1638. doi:10.1007/s10098-020-01918-8
Santos N.D.S.A., Alvarez C.E.C., Roso V.R., Baeta J.G.C., Valle R.M., 2021, Lambda load control in spark ignition engines, a new application of prechamber ignition systems, Energy Conversion and Management, 236, 114018. doi.org/10.1016/j.enconman.2021.114018

Saraswat M., Chauhan N.R., 2020, Comparative assessment of butanol and algae oil as alternate fuel for SI engines, Int. J. Eng. Sci. Technol., 23 (1), 92-100. doi:10.1016/j.jestch.2019.04.002

Schäfer F., Basshuysen R.V., 1995, Reduced Emissions and Fuel Consumption in Automotive Engines, SpringerVerlag Wien New York and Society of Automotive Engineers Inc., Warrendale.

Schifter I., Díaz L., Vera M., Guzmán E., López-Salinas E., 2004, Fuel formulation and vehicle exhaust emissions in Mexico, Fuel, 83 (14-15), 2065-2074. doi.org/10.1016/j.fuel.2004.03.017

Shayler P.J., Chick J., Darnton N.J., Eade D., 1999, Generic functions for fuel consumption and engine-out emissions of $\mathrm{HC}, \mathrm{CO}$ and $\mathrm{NO}_{\mathrm{x}}$ of spark-ignition engines, Proceedings of the Institution of Mechanical Engineers, Part D: Journal of Automobile Engineering, 213 (4), 365-378. doi:10.1243/0954407991526937

Shen H., Shamim T., Sengupta S., 1999, An investigation of catalytic converter performances during cold starts, SAE Technical Paper, 1999-01-3473 ISSN 0148-7191. doi:10.4271/1999-01-3473

Shenghua L., Clemente E.R.C., Tiegang H., Yanjv W., 2007, Study of spark ignition engine fueled with methanol/gasoline fuel blends, Applied Thermal Engineering, 27 (11-12), 1904-1910. doi:10.1016/j.applthermaleng.2006.12.024

Sivasubramanian H., Pochareddy Y.K., Dhamodaran G., Esakkimuthu G.S., 2017, Performance, emission and combustion characteristics of a branched higher mass, $\mathrm{C}_{3}$ alcohol (isopropanol) blends fuelled medium duty MPFI SI engine, Int. J. Eng. Sci. Technol., 20 (2), 528-535. doi:10.1016/j.jestch.2016.11.013

Speight J.G., 2011, Fuels for Fuel Cells (Chapter 3) in: Shekhawat D., Spivey J.J., Berry D.A. (Eds.) Fuel Cells: Technologies for Fuel Processing, Elsevier Science pp. 29-48. doi.org/10.1016/B978-0-444-53563-4.10003-3

Şimşek D., Oral F., Çolak N.Y., 2019, The effect on engine performance and emissions of gasoline-propanolhexane fuel blends on single cylinder spark-ignition engines, Journal of Thermal Sciences and Technology, 39 (1), 81-89. (In Turkish)

Varol Y., Öner C., Öztop H.F., Altun Ş., 2014, Comparison of methanol, ethanol, or n-butanol blending with unleaded gasoline on exhaust emissions of an SI engine, Energy Sources, Part A: Recovery, Utilization, 
and Environmental Effects, 36 doi:10.1080/15567036.2011.572141

Wu C.W., Chen R.H., Pu J.Y., Lin T.H., 2004, The influence of air-fuel ratio on engine performance and pollutant emission of an SI engine using ethanolgasoline-blended fuels, Atmospheric Environment, 38 (40), 7093-7100.

doi.org/10.1016/j.atmosenv.2004.01.058

Yu S., Min K., 2002, Effects of the oil and liquid fuel film on hydrocarbon emissions in spark ignition engines, Proceedings of the Institution of Mechanical Engineers, Part D: Journal of Automobile Engineering, 216 (9), 759-771. doi: 10.1243/09544070260340853
Zhao H., Ge Y., Tan J., Yin H., Guo J., Zhao W., Dai P., 2011, Effects of different mixing ratios on emissions from passenger cars fueled with methanol/gasoline blends, Journal of Environmental Sciences, 23 (11), 1831-1838. doi: 10.1016/S1001-0742(10)60626-2 